\title{
Opinie
}

\section{Interpretacja jako kryptonimia, czyli Nicolasa Abrahama i Marii Torok czytanie zakrzywione ${ }^{1}$}

Ireneusz Piekarski

TEKSTY DRUGIE 2016, NR 5, S. 275-299

DOI: $10.18318 /$ td.2016.5.18

Obawiam się, że to właśnie w tym miejscu czytelnicy przestaną wierzyć w to, co mówię.

S. Freud ${ }^{2}$

Jesteśmy w pełni świadomi, że to, co tutaj proponujemy, jest niesłychanie śmiałe. Musimy zebrać się na odwagę, by zaprezentować Państwu niezwykłe rezultaty naszego wsłuchiwania się.

N. Abraham, M. Torok ${ }^{3}$

$\mathbf{N}$ icolas Abraham (1919-1975) i Maria Torok (1925-1998) to myśliciele i terapeuci słabo w Polsce

1 Artykuł ten jest fragmentem większej całości poświęconej nowszym strategiom lekturowym.

2 S. Freud Z historii nerwicy dziecięcej, w: Dwie nerwice dziecięce, przeł. R. Reszke, KR, Warszawa 2000, s. 125.

3 N. Abraham, M. Torok The Wolf Man's Magic Word: a Cryptonymy, transl. N. Rand, University of Minnesota Press, Minneapolis 1986, s. 32.
Ireneusz Piekarski

- dr, adiunkt w Katedrze Teorii i Antropologii Literatury KUL. Autor książki Z ciemności. O twórczości Juliana Stryjkowskiego (2010), współredaktor tomów Psychoanalityczne interpretacje literatury (2012) oraz Interpretacja kerygmatyczna (2014). Obecnie przygotowuje antologię Wbrew przeznaczeniu. Proza hebrajskiego odrodzenia narodowego. Kontakt: irreus@ gmail.com 
znani $^{4}$, a w środowisku francuskiej psychoanalizy freudowskiej obecni od końca lat 50. XX wieku. Abraham został psychoanalitykiem w 1959, Torok - trzy lata wcześniej. Jednakże - jak w szkicu biograficznym zanotował Nicholas Rand - instytucjonalna psychoanaliza (zarówno freudowska,jak i lacanowska) zignorowała ich propozycje teoretyczne i metapsychologiczne ${ }^{5}$. Co więcej, sam Abraham był w Paryskim Towarzystwie Psychoanalitycznym (SPP) traktowany jako persona non grata i przez lata cierpiał z powodu ostracyzmu rodzimej organizacji ${ }^{6}$. Dopiero po śmierci, od momentu ukazania się jego książki napisanej wspólnie z Marią Torok Cryptonymie: Le Verbier de l'Homme aux loups (1976), która „odniosła niesłychany sukces"7, sytuacja zaczęła się zmieniać. Tę (nieco szaloną ${ }^{8}$ ) interpretację zachowań, snów i wspomnień Człowieka-wilka wraz z prezentacją jego idiosynkratycznego verbier, czyli jak moglibyśmy powiedzieć po polsku: słowarium, poprzedził

4 Myśl francuskich psychoanalityków zwięźle zaprezentowała Z. Kolbuszewska Transpokoleniowy fantom, krypta, kryptonimia i anasemia: w kręgu neo-freudowskiej herezji Nicolasa Abrahama i Marii Torok, w: Psychoanalityczne interpretacje literatury. Freud - Jung - Fromm - Lacan, red. E. Fiała, I. Piekarski, Wydawnictwo KUL, Lublin 2012. W kontekście Derridiańskiej hauntologii o koncepcji Abrahama i Torok pisali: A. Marzec Widma, zjawy i nawiedzone teksty-hauntologia Jacques'a Derridy, czyli pośmiertne życie literatury, w: Wymiary powrotu w literaturze, red. M. Garbacik et al., Wydawnictwo Libron, Kraków 2012, s. 255-262; M.P. Markowski Polityka wrażliwości. Wprowadzenie do humanistyki, Universitas, Kraków 2013, s. 158-164; J. Momro Widmontologie nowoczesności. Genezy, Wydawnictwo IBL PAN, Warszawa 2014 (zwłaszcza podrozdział Nieme słowa, s. 357-386).

5 Zapewne dlatego, że stanowiły one trzecią drogę, jak zauważył Rand (Biographies de Nicolas Abraham et de Maria Torok, http://abraham-torok.org/association/biographies-abraham-et-torok/ (29.02.2016), między ortodoksyjnym freudyzmem a ujęciami lacanowskimi.

6 Zob. N. Rand Biographies... Kulisy sprawy odrzucenia wniosku Abrahama o członkostwo w IPA oraz wcześniejsze pomówienia dotyczące "strasznego sekretu" z jego życia (z końca lat 50. XX wieku) omawia też E. Roudinesco La bataille de cent ans. Histoire de la psychanalyse en France. 1925-1985, vol. 2, Éditions du Seuil, Paris 1986, s. 603-604.

7 Tamże, s. 603.

8 Jeden z komentatorów napisał, że studium Abrahama i Torok to „najbardziej ambitna a równocześnie nieodpowiedzialna [erratic] próba, jaka kiedykolwiek została podjęta dla wykreślenia wewnątrzpsychicznej struktury nieśmiertelnego pacjenta Freuda". Zob. P. Mahony Cries of the WolfMan, International Universities Press, New York 1984, s. 35.

9 "Człowiek-wilk" lub "Człowiek od wilków" (Wolfsmann) to pseudonim po raz pierwszy użyty w literaturze psychoanalitycznej w 1928 roku przez uczennicę Freuda Ruth Mack Brunswick (zob. E. Roudinesco, M. Plon Dictionnaire de la psychanalyse, Fayard, Paris 1997, s. 757), którym to słynny pacjent Freuda, Sergiej Konstantinowicz Pankiejew, podpisywał później również własne wspomnienia i rozmowy. 
często cytowany później obszerny i instruktywny wstęp pióra Jacques'a Derridy ${ }^{\mathbf{1 0}}$ (przyjaciela Abrahama) - który na pracę dwojga psychoanalityków zwrócił uwagę środowiska poststrukturalistycznie zorientowanych badaczy. Wkrótce pojawiło się niemieckie tłumaczenie Le Verbier (1979), potem angielskie (1986), włoskie (1992) i japońskie (2006). W 1978 roku wyszła druga książka Abrahama i Torok: L'écorce et le noyau ", tym razem gromadząca ich rozproszone artykuły teoretyczne i metodologiczne (również te niepublikowane ${ }^{\mathbf{1 2}}$. Jej angielskie tłumaczenie pt. The Shell and the Kernel ukazało się w roku $1994^{13}$. W tym samym roku paryski periodyk „Etudes Freudiennes” został zadedykowany „obecności Abrahama”. Z kolei w latach 80. magazyn „Confrontations” w nawiązaniu do myśli Torok i Abrahama wydał kilka numerów poświęconych problematyce fantomów, telepatii, palimpsestu, psychoanalitycznej interpretacji, de-szyfracji. W 1999 roku, już po śmierci Torok, powstało stowarzyszenie (Association Européenne Nicolas Abraham et Maria Torok), mające za zadanie prezentację i krzewienie myśli (zarówno teoretycznej, jak i klinicznej) tych dwojga niekonwencjonalnych myślicieli. Stowarzyszenie istnieje do dziś, wydaje książki, organizuje cykliczne kolokwia i przyznaje nagrody. Jak poświadczają bibliografie ${ }^{14}$, od lat 8o. nastąpił duży

10 J. Derrida Fors: Les mots anglés de Nicolas Abraham et Maria Torok, przekład angielski: Fors: The Anglish words of Nicolas Abraham and Maria Torok, transl. B. Johnson; przekład polski: Fora. "Kanciaste" słowa Nicolasa Abrahama i Márii Török, przeł. B. Brzezicka, "Teksty Drugie” 2016 nr 2.

Derrida napisał także "wstęp" (Me - Psychoanalysis: an Introduction to the Translation of "The Shell and the Kernell" by Nicolas Abraham, transl. R. Klein) do angielskiego tłumaczenia tytułowej rozprawy Abrahama The Shell and the Kernel. Oba teksty ukazały się w 1. nrze "Diacritics" z 1979 roku zatytułowanym The Tropology of Freud.

12 Później wyszły kolejne prace Abrahama: Jonas et Le Cas Jonas (Aubier, Paris 1981), książka będąca tłumaczeniem węgierskiego poematu M. Babitsa Jónás könyve i psychoanalitycznym doń komentarzem, oraz Rythmes. De l'œuvre, de la traduction, et de la psychanalyse (Flammarion, Paris 1985) - zbierająca jego wczesne (z lat 1948-1962) rozprawy z fenomenologii twórczości i psychoanalitycznej estetyki. W 1997 ukazała się wspólna książka Torok i Randa Questions for Freud. The Secret History of Psychoanalysis (Harvard University Press, Cambridge-London) a w 2002 pośmiertny tom zbiorowy Torok Une vie avec psychanalyse: inedits et introuvables (Aubier, Paris 2002), gromadzący jej rozproszone i niewydane artykuły z lat 1953-1996.

13 Edycja ta znacznie różni się od tomu francuskiego. Angielskie wydanie podzielono na dwa woluminy, z tym że drugi, jak dotąd, się nie ukazał.

14 Adnotowane bibliografie podmiotowe i przedmiotowe Abrahama i Torok (do 1996) sporządził P. Hachet Bibliographie analytique des travaux de Nicolas Abraham, de Maria Torok et des auteurs qui y ont fait réferénce (jusqu'en 1996). „Le Coq-héron” 2006 no 3 (186); uzupełnienia i poprawki w kolejnym nrze (187). Nr 186 "Le Coq-héron" zatytułowany Symboles, cryptes et fantômes 
wzrost zainteresowania propozycjami francuskich psychoanalityków, które obecnie zyskały międzynarodowy rozgłos ${ }^{15} \mathrm{i}$ - w pewnych kręgach - status klasyki.

Zanim przejdę do zaprezentowania interpretacji kryptonimicznej, chciałbym rzec parę słów o jej tle - o Freudowskim objaśnieniu snu Człowieka-wilka.W ujęciu ojca psychoanalizy sen o białych wilkach siedzących nieruchomo na orzechu i wpatrujących się w chłopca to oniryczny komunikat, mówiący - poprzez uaktywnienie dawnego obrazu - o naturze stosunku seksualnego: męskości i kobiecości (aktywności i bierności), przeradzający się w lęk, lęk przed kastracją i przed kastrującym ojcem (wyprostowanym wilkiem z wyciągniętą łapą). Choć w uzyskanym materiale analitycznym pojawiają się też inne dramatis personae: matka, niania, siostra, służąca, guwernantka, nauczyciel, to zrekonstruowany przez autora Objaśniania marzeń sennych dramat rodzinny dotyczył niemal wyłącznie relacji syna z ojcem i skutkował nerwicą tego pierwszego, która dzięki terapii psychoanalitycznej, jak mniemał Freud w momencie spisywania historii tej choroby, czyli zimą 1914-1915, została w znacznej mierze opanowana.

Jak senną historię o wilkach na orzechu czytają 60 lat później Nicolas Abraham i Maria Torok? Czytają przede wszystkim przez pryzmat wypracowanych przez siebie w latach 6o. koncepcji introjekcji, inkorporacji, antymetafory, rozłamanego symbolu i anasemii. A również z dostępnymi im materiałami dodatkowymi, zawartymi następnie w książce opracowanej przez Muriel Gardiner The Wolf-Man by the Wolf-Man. Tom ten zawiera zarówno bardzo istotne dla analityków wspomnienia Człowieka-Wilka z jego dzieciństwa (też z młodości, z czasów analizy z Freudem i późniejsze, sięgające roku 1938), jak i migawkowe świadectwa Gardiner (przede wszystkim z lat 1938-1949, 1956) oraz ważną dla francuskich badaczy diagnozę (z 1928) drugiej terapeutki Pankiejewa, czyli Ruth Mack Brunswick.

Można bez żadnej przesady powiedzieć, że lektura Abrahama i Torok to przejście od „symbolistycznej” poetyki obrazu do poetyki „fonizującej”. Dla Freuda traumatyzujący rysunek w książeczce dla dzieci, przedstawiający

w całości poświęcony został Abrahamowi i Torok. Lista publikacji autorskich Abrahama i Torok także na stronie http://abraham-torok.org/publications/publications-abraham-et-torok/ (11.11.2016). Tu znajduje się również obszerna bibliografia ogólna prac psychoanalitycznych związanych z propozycjami francuskich psychoanalityków (sięgająca roku 2013).

15 Zob. N. Rand Biographies... Zob. teżE. Roudinesco La bataille de cent ans..., s. 603; C. Davis Haunted Subjects. Deconstruction, Psychoanalysis and the Return of the Dead, Palgrave Macmillan, Houndmills-New York 2007. 
stojącego wilka - s y m b o li z u j e ojca, z kolei wspomnienie pomywaczki na kolanach z wypiętymi pośladkami o b r a z u j e matkę. Dla Abrahama i Torok ważne są zaś przede wszystkim paronimy i wszelkie asocjacje brzmieniowe (najczęściej określane jako „rymy”). Ich analiza przebija się jednak w ostatecznym rozrachunku przez warstwę glosolaliczną do poziomu ukrytego znaczenia i niebezpośrednich przekształceń semantycznych, czyli kryptonimów. Droga do przemieszczonego sensu w przypadku Człowieka-wilka wiedzie m.in. przez przekład interlingwalny, ale specyficznie pojmowany, gdyż to, co francuscy psychoanalitycy bardzo często robią w trakcie interpretacji jego snu, to coś w rodzaju translacji - jak moglibyśmy powiedzieć - „paronomastycznej”, nijak nie mieszczącej się np. w lingwistycznym schemacie Romana Jakobsona, wyróżniającego, przypomnijmy: 1. przekład wewnątrzjęzykowy, czyli przeredagowanie, 2. międzyjęzykowy, czyli właściwy, i 3. intersemiotyczny, czyli transmutację $e^{16}$.

Żeby wstępnie zobrazować tę niezwykłą procedurę badawczą Abrahama i Torok, można by posłużyć się dowcipnym przykładem podanym przez Juliana Tuwima. Oto słowa depeszy - które zanotował autor Pegaza dęba w rozdziale o naśladowaniu obcych języków - napisanej z Monte Carlo przez syna utracjusza do rodziców: „Six joues baise[nt] gros chat”. I dziwnie beznamiętna odpowiedź z Rosji: „Nous ici dis”. Ów, zdałoby się, kubistyczny i silnie zmetaforyzowany obraz sześciu policzków całujących tłustego kota, po którym następuje podniosła formuła potwierdzenia przyjęcia komunikatu - w „paronomastycznym przekładzie" na rosyjski nagle zaczyna nabierać sensu przyziemnego, merkantylnego wręcz i zgoła ironicznego, gdyż „usłyszany” w języku Puszkina dialog ów brzmi następująco: - Сижу без гроша - depeszuje syn. - Ну и сиди - ripostuje wyraźnie rozeźlony rodzic ${ }^{17}$. Anegdota ta funkcjonuje w kilku wariantach. Ten, który właśnie wykorzystaliśmy, zanotował Władimir Aleksandrowicz Słobodczikow ${ }^{\mathbf{1 8}}$. Inny - w naszym kontekście znacznie ciekawszy (bo szpiegowski) - jest taki, że to graf Karl Nesselrode wysłał z Paryża do cara Aleksandra I tajną wiadomość następującej treści: „Шесть щек целуют толстого кота”. Nawet przechwycona

16 R. Jakobson O językoznawczych aspektach przekładu, przeł. L. Pszczołowska, w: Współczesne teorie przekładu. Antologia, red. P. Bukowski, M. Heydel, Znak, Kraków 2009, s. 44. W dosłownym tłumaczeniu: "- Siedzę bez grosza. - No to siedź”. doty, ani jej kontekstu. Zob. B.A. Слободчиков О судьбе изгнанников печальной, Центрполиграф, Москва 2005. 
odpowiedź z Moskwy w języku francuskim: „Nous ici dis” w niczym nie pomogła zrozpaczonym kryptologom Napoleona Bonaparte (choć zapewne graf też nie był z niej zadowolony...).

Wielojęzyczność to często podkreślana cecha żydowskiego doświadczenia i edukacji w diasporze. Poruszanie się między kilku czy nawet kilkunastoma językami nie było niczym nadzwyczajnym, zwłaszcza dla żydowskich mężczyzn. Amos Oz wspominał, że np. jego ojciec potrafił czytać w 17 językach, matka mówiła zaś pięcioma. Podobnie Roman Zimand podkreślał, że ojciec znał pięć języków i żadnego nie traktował jako obcego ${ }^{19}$. I było to, dodajmy, swoistą normą. Polilingwizm cechował również Nicolasa Abrahama i Marię Torok. Abraham w latach 30. był studentem jesziwy - wyższej uczelni talmudycznej - władał więc nie tylko językiem węgierskim i prawdopodobnie jidysz, ale także hebrajskim i aramejskim. Oprócz ortodoksyjnego otrzymał również wykształcenie świeckie, zdał maturę z przedmiotów matematyczno-przyrodniczych, oprócz wymienionych języków dobrze znał też grekę, francuski i niemiecki. Torok zaś była w liceum prymusem z łaciny, a po przyjeździe do Francji biegle opanowała francuski.

Wspominam o tym dlatego, że odkrycie, którego dokonali na pewnym etapie swoich studiów nad Człowiekiem-wilkiem, polegało właśnie na wyciągnięciu konsekwencji z faktu, zaobserwowanego już przez Freuda, że mały Sierioża był bilingwalny. Oprócz rosyjskiego używał on bowiem przynajmniej w podstawowym zakresie - języka swojej nielubianej guwernantki, czyli angielskiego ${ }^{20}$. A i później, zarówno w dzieciństwie, jak i do-

19 Zob. B. Harshav Wielojęzyczność, przeł. A. Kondrat, "Cwiszn" 2011 nr 1-2, s. 7; Ch. Shmeruk Hebrajska - jidysz - polska. Trójjęzyczna kultura żydowska, przeł. M. Adamczyk-Garbowska, "Cwiszn" $2011 \mathrm{nr}$ 1-2, s. 24.

20 Zauważmy na marginesie, że w samych wspomnieniach Człowieka-wilka (zob. M. Gardiner The Wolf-Man by the Wolf-Man, Basic Books, New York 1971) nie ma zbyt wielu dowodów potwierdzających tę opinię. Znajduje się tam za to sporo materiału sugerującego, że Sergiusz Pankiejew mógł znać po trosze... język polski. Miss Oven, angielska guwernantka, zanim została zwolniona, spędziła z dziećmi zaledwie kilka miesięcy. Natomiast kolejna nauczycielka Anny i Sergiusza, Szwajcarka - nazywana przez domowników Mademoiselle - która wcześniej pracowała na dworach Zamoyskich, Potockich i Mniszków, posługiwała się czymś w rodzaju dialektu polsko-rosyjskiego (s. 30). Mademoiselle ze swoją łamaną polszczyzno-ruszczyzną przez długi czas zajmowała się rodzeństwem, zresztą, pozostała z rodziną Pankiejewów aż do śmierci. Ciekawa w tym kontekście jest także informacja, że druga żona wujka Aleksego była Polką, a chłopiec bywał u nich w odwiedzinach. Tuż przed samobójstwem siostry przeżył w domu wujostwa młodzieńczy romans, mianowicie zakochał się z wzajemnością w odwiedzającej ciocię dziewczynie z Polski, w (archetypicznie) pięknej niebieskookiej blondynce Marcie (s. 37). Z kolei pierwsza żona wujka Bazylego była polską śpiewaczką operową. Jenny, ich córka, po 
rosłym życiu, nieustannie przemieszczał się między językami: niemieckim, francuskim i rosyjskim ${ }^{21}$ (w pewnym momencie zafascynowało go nawet językoznawstwo porównawcze ${ }^{22}$ ), natomiast po latach nieużywania języka angielskiego zapomniał go... ale jak założyli dociekliwi psychoanalitycy, język pierwszej guwernantki pozostał w nim, stając się nieuświadamianym medium kodującym, swoistym pryzmatem załamującym znaczenia i je rozszczepiającym ${ }^{\mathbf{2 3}}$.

To właśnie dzięki tej obserwacji Torok i Abraham potrafili, mówiąc językiem kryptologów, przejść z poziomu dekryptażu (odczytywania kryptogramów bez znajomości klucza, co zajęło im trzy lata) na poziom d e s zy fr a cji (literowego przekładu za pomocą klucza) a raczej o d ko d o wa n ia (dzięki wyobraźniowemu zrekonstruowaniu hipotetycznej książki kodowej, czyli w przypadku Człowieka-wilka „słowarium”), co trwało kolejne dwa lata.

Roman Jakobson tak pisał o rozszyfrowywaniu i dekodowaniu tekstów w nieznanym badaczowi języku:

Zakłada się, że adresat szyfrowanego tekstu zna kod i przy jego pomocy rozszyfrowuje komunikat. W przeciwieństwie do tego kryptanalityk dostaje tekst nie znając kodu leżącego u jego podstaw i musi znaleźć ten kod manipulują c odpowiednio tekstem. [...] Językoz naw c a, który ma zamiar badać zupełnie nieznany język, zaczyna tak jak kryptanalityk,

rozwodzie zaniedbywana przez ojca, obracała się głównie w "polskich kręgach" i dzięki temu na równi z rosyjskim "opanowała język polski" (s. 79). W świetle tych wspomnień i rodzinnych koligacji można by założyć, że polszczyzna nie była całkiem obca naszemu bohaterowi.

O tym, że angielski oprócz rosyjskiego i francuskiego stanowił jednak trwały element składowy makaronicznych konstrukcji z lubością używanych przez rosyjską arystokrację pod koniec XIX wieku, zaświadcza trójjęzyczny fragment z Anny Kareniny: „И потом, c'est un intérieur si joli, si comme il faut. Tout-a-fait a l'anglaise. On se réunit le matin au breakfast et puis on se sépare. Всякий делает что хочет до обеда". Zwrócił nań uwagę R. Jakobson (R. Jakobson, M. Halle Podstawy języka, przeł. L. Zawadowski, Ossolineum, Wrocław-Warszawa-Kraków 1964, S. 56).

N. Abraham, M. Torok The WolfMan's magic word, s. 31.

23

Opalizujący znaczeniem podtytuł wstępu J. Derridy: Les mots anglés, jest i nawiązaniem do zapomnianej angielszczyzny Człowieka-wilka, i do traktatu filologicznego S. Mallarmégo Les mots anglais (antycypującego nieco późniejszą i równie osobliwą teorię języka innego poety, Wielimira Chlebnikowa), i do techniki zniekształcania słów ukazanej przez autorów Kryptonimii (fr. neologizm kontaminacyjny anglés to zarówno aluzja do angielszczyzny <anglais>, jak i do słowa, które znaczy: kąt, róg <angle>). Zob. też J. Derrida Mallarmé (1974), przeł. A. Zawadzki, w: Sztuka interpretacji w ostatnim półwieczu, t. 3, oprac. H. Markiewicz, Universitas, Kraków 2011. 
aż stopniowo odkrywając kod osiąga to, że może dekodować każdy tekst w tym języku, tak jakby to był jego własny język. ${ }^{24}$

Jeśli zamienimy „językoznawcę” na psychoanalityka, otrzymamy opis wyjściowej sytuacji autorów Kryptonimii. Fraza „manipulacja tekstem” dobrze zaś oddaje to, co robią Abraham i Torok, którzy określając swoje czynności, pisali o „maj strow a n i u przy słowach” czy „s z pera niu w nich” (s. 17).

Autorzy Le Verbier de l'Homme aux loups nie znali wprawdzie rosyjskiego, ale eufoniczne poetyckie ucho Abrahama - który przełożył na francuski m.in. utwory Mihály'ego Babitsa - być może również jego talmudyczne wykształcenie $^{25}$ i polilingwizm obojga popchnął ich ku hipotezie „fonicznej” $i$,permutacyjnej” oraz ku intuicyjnej pracy ze słownikami języka rosyjskiego. Zapewne w trakcie swych badań psychoanalitycy korzystali też z konsultacji lub językowych porad rodzimych użytkowników języka rosyjskiego ${ }^{\mathbf{2 6}}$. Dziwić może jednak, że nie zechcieli skorzystać z gotowego, istniejącego tłumaczenia rozprawy Freuda na rosyjski z 1925 roku², co zaoszczędziłoby im mnóstwa pracy, zgadywania i (twórczych) błędów ${ }^{\mathbf{2 8}}$, choć zapewne pozbawiłoby jednocześnie

24 R. Jakobson, M. Halle Podstawy języka, s. 55.Wyróżnienia w tekście - I.P.

25 O wpływie rabinicznej filozofii tekstu i metodologii lektury na wielu, głównie XX-wiecznych, myślicieli, m.in. na S. Freuda, J. Derridę, H. Blooma, pisze S.A. Handelman The Slayers of Moses. The Emergence of in, State University of New York Press, Albany 1982.

26 Ktoś - wydaje się - musiał im np. podsunąć informację, że „buka” znaczy po rosyjsku wilk (s. 18-19). Informacja ta nie znajduje dziś potwierdzenia w słownikach i encyklopediach. W folklorze słowiańskim buka to potwór porywający i pożerający dzieci, mieszkający pod łóżkiem i w szafie, niewidoczny dla dorosłych, włochaty i z wielką paszczą, ale raczej nie wilk, może nieco podobny do niedźwiedzia. Zob. Л.Р. Хафизова Бука как персонаж детского фольклора, w: Славянский и балканский фолклор. Народнаяя демонологя, red. Л.Н. Виноградова, С.М. Толстая, Е.Е. Левкиевская, Москва 2000. Serdecznie dziękuję dr. Albertowi Nowackiemu z IFS KUL za „bukologiczne” konsultacje i wskazanie oraz udostępnienie mi tego ciekawego i cennego źródła.

27 3. Фрейд Из истории одного детского невроза, w: Психоанализ детских неврозов, przeł. О.Б. Фельцман, М.В. Вульф, Москва-Ленинград 1925.

28 W zasadzie nikt nie zwracał uwagi na transkrypcyjne potknięcia autorów Magicznego słowa. Jedynie D. Robinson (Who? Translator, State University of New York Press, New York 2001, s. 86) zauważył en passant błędny zapis słowa rpex (grzech) jako khriekh (zamiast griekh). Nieco poważniejsze konsekwencje pociąga za sobą jednak stale stosowana przez Abrahama i Torok forma "siestiorka” (we franc. oryginale: „siestierka”), zamiast siestrionka czy siestriczka (сестрёнка lub сестричка, czyli siostrzyczka), gdyż na takiej właśnie błędnej postaci fonetycznej budują swoje główne interpretacje. Wszyscy późniejsi komentatorzy, z Derridą włącznie, powtarzają ten błędny zapis. 
uroków rozglądania się wokół i całkiem swobodnego wyboru haseł i skojarzeń. Dodajmy też, że na podstawie gotowego przekładu nie doszliby zapewne do zaprezentowanych w swojej książce wniosków, ponieważ tłumacze, Wulf i Felcman, często szli inną ścieżką leksykalną, bardziej naturalną i wierną, niż - nieznający rosyjskiego - Abraham i Torok, którzy podążali przede wszystkim za własną hipotezą inkorporacji, a nie za realiami językowymi...

Człowiek-wilk rozmawiał z Freudem oczywiście po niemiecku i w tym języku został spisany jego słynny sen. „Ich habe geträumt, dass es Nacht ist, und Ich in meinem Bett liege" - czytamy w „oryginale” Z historii pewnej nerwicy dziecięcej. Jednak dopiero u sły s z a ny po rosyjsku materiał zaczyna wyjawiać (a raczej wyszeptywać, ponieważ pozostajemy na poziomie dźwięku i sekretu) niektóre swoje tajemnice i umożliwia psychoanalitykom zejście (ponieważ to ruch regresywny, anasemiczny właśnie) na poziom słów pierwotnych, czyli archeonimów, jak je nazywają. Pierwsza podpowiedź o charakterze „brzmieniowym” pochodziła od samego Człowieka-wilka, który już w trakcie analizy zasugerował Freudowi, że zdanie z jego snu o otwierającym się oknie: „Plötzlich geht das Fenster von selbst auf”, powinno zostać zrozumiane jako: nagle otworzyły się oczy ${ }^{29}$. Po rosyjsku bowiem - tego już Pankiejew Freudowi nie powiedział - zdanie to brzmi następująco: „Вдруг окно само распахнулось". Po polsku słychać to i widać jeszcze wyraźniej ${ }^{30}$. Okno - oko. To parechesis. Mówię okno, skrywam, ale i sugeruję oko, a nawet coś więcej. To - można by rzec - funkcja poetycka na usługach funkcji... represywnej, kryptonimicznej.

Nagle okno samo się otworzyło - nagle otworzyły się oczy. I co zobaczyły? - pytają oczywiście psychoanalitycy. Freud wydedukował w tym momencie obraz kopulujących rodziców. Abraham i Torok bardziej niż oczom ufają jednak uszom i do swojej hipotezy dochodzą przez warstwę brzmieniową. Dlaczego piszę okno, a myślę oko? Po co ten cały paronomastyczny romans optyczny? Zaryzykowaliśmy i rym, i anagram jako swoiste exempla, gdyż za chwilę pojawią się one w samym centrum dowodzenia autorów Magicznego słowa. Słownikowe hasło „око” wizualnie odesłało bowiem naszych kryptologów-amatorów do słów mu pokrewnych: очевидец, очевидно. Mamy więc i świadka (naocznego): tego, który widzi (видец) własnymi oczami (оче), i oczywistość: to, co widać własnymi oczami (оче) i co jest

S. Freud Z historii pewnej nerwicy dziecięcej, s. 123. 
bezdyskusyjne (видно). Co więcej, mamy kontaminacyjne zestawienie oczu i okna - anagramatycznie wprowadzonego w języku angielskim: ocze-widno - window (zwróćmy uwagę, że tym razem to anagram literowy, nie foniczny). W очевидец, dodajmy już od siebie, można by się dosłuchać znacznie subtelniejszych aluzji, mianowicie kluczowego słowa: ојсіес (отец) lub ojcze (отче).Wskazuje na nie bowiem układ samogłosek (o-e-e), oraz - jak powiedziałby Ferdinand de Saussure - kompleks anagramatyczny: o - ec, tworzący wyraziste ramy hipogramu ${ }^{31}$.

Spróbujmy nieco uporządkować dotychczasowe meandryczne wywody, niemieckie „Fenster” znaczy więc przez rosyjskiego pośrednika najpierw w postaci okna (semantycznie), następnie - oka (fonetycznie), które odsyła z kolei do formy pokrewneј очевидец - naocznego świadka, czyli po angielsku „witness”. Witness z kolei współbrzmi, „rymuje się (angramatycznie) 32” z innym archeonimem ze snów Człowieka-wilka, mianowicie Whitsunday (Zielone Świątki), które dodatkowo wprowadza syna (sun - son) oraz perspektywę czasową (day - dzień). Dzień, w którym syn był świadkiem: Whitsun = witness of the son. „Teraz to mówi!” - wykrzykują zdumieni kryptolodzy (s. 34). Każdy element w niemieckim zdaniu zyskuje swój semantyczny ekwiwalent rosyjski, a następnie angielski w postaci paronimu: Plötzlich (nagle) = вдруг (nagle) = the truth (prawda). „Selbst” („samo”) Abraham i Torok tłumaczą jako „само собои” (samo z siebie, samo przez się), co z kolei zostaje rozszyfrowane jako „somewhat as a boy" (trochę <? > jako chłopiec). Fenster $=$ окпо $=$ око $=$ очевидец $=$ witness (świadek). Zdanie: Nagle otworzyło się okno (Plötzlich geht das Fenster von selbst auf - Вдруг окно само распахнулось), po zdeszyfrowaniu oznacza więc: Prawda jest taka, że świadek otworzył się przede mną jako chłopiec.

Zob. J. Starobinski Les mots sous les mots. Les anagrammes de Ferdinand de Saussure, Gallimard, Paris 1971, s. 70.

Jeśli zredukujemy wyrazy do ich uproszczonych postaci spółgłoskowych (niczym w zapisie hebrajskim), otrzymamy wyraziste równanie WTNS = WTSN (dodajmy, że zabieg ten przypomina jedną z kabalistycznych technik lektury, technikę anagramowania, czyli temurę, lub może raczej rabiniczną zasadę egzegetyczną al tikrei, czyli regułę odmiennego odczytania ustalonej wersji masoreckiej, żeby uzyskać nowe znaczenie, wykraczające poza sens literalny. Uzyskuje się je przez zmianę wokalizacji, przestawienie lub zamianę liter). Inny przykład takiej konsonantycznej permutacji i zbudowanego na niej równania i interpretacji to np. tieret (теретъ, trzeć) - rtut (ртутъ, rtęć): TRT = RTT. Zob. N. Abraham, M. Torok Mourning or melancholia: Introjection versus Incorporation, w: The Shell and the Kernel. Renewals of Psychoanalysis, vol. 1, transl. N.T. Rand, University of Chicago Press, Chicago-London 1994, S. 133. 
Tak zostaje przeczytany i przetłumaczony cały - niedługi wprawdzie - sen Człowieka-wilka. Sylaba po sylabie, słowo po słowie, zdanie po zdaniu (choć im dalej, tym „tłumaczenie” robi się jeszcze bardziej problematyczne). Co więcej, wszystkie jego sny, które zostały zgromadzone w książce Gardiner, zostają odszyfrowane w ten lub podobny sposób! Np.: Zimmer (pokój) = зимой $($ zimą) = it’s a boy (to chłopiec); butterfly (motyl) = better to lie (lepiej skłamać); Unglück (nieszczęście) $=$ pech $=$ пех $=$ г-pex; Stern $($ gwiazda $)=$ звезда = сестра $=$ sister $($ siostra $) ;$ Halbmond $($ półksiężyc $)=$ Sigmund $=$ ojciec $($ Freud jako figura ojcowska), Nase (nos) = knows (on wie). Jeśli zawiesimy niewiarę w sensowność całego tego glosolalicznego-rebusowego przedsięwzięcia i (nie tylko lingwistyczny) krytycyzm ${ }^{33}$, to należałoby uznać, że robocza „angielska" hipoteza zadziałała jak magiczne zaklęcie zdejmujące czar nieczytelności lub raczej zwodniczej czytelności z tekstu-życia Człowieka-wilka. Zmieniając zaś słownik bajkowy na szpiegowski, moglibyśmy powiedzieć nawet, że zadziałała niczym kryptologiczna bomba Mariana Rejewskiego.

Wstępnie podsumujmy, procedura zastosowana przez Abrahama i Torok jest analogiczna do odczytywania szyfrogramów. Niemal to samo - w mniejszej skali i z większą precyzją - zrobił przecież graf Nesselrode. Napisał po rosyjsku tekst, który należało przetłumaczyć na francuski i dopiero wtedy usłyszeć go znów po rosyjsku. W przypadku Człowieka-wilka podstawowy algorytm jest następujący: niemiecki tekst przetłumaczony na rosyjski trzeba usłyszeć po angielsku.

Cytowane już zdanie początkowe: „Ich habe geträumt, dass es Nacht ist” („Śniło mi się, że jest noc”) zostaje zdeszyfrowane z kolei jako: „Świadkiem jest syn, nie ty". Czytanie opiera się tu na dokładnie tych samych mechanizmach przekładu interlingwalnego i paronomastycznego jednocześnie: „Ich habe geträumt" na rosyjski przetłumaczone zostaje јako видетъ сон i usłyszane po angielsku jako witness son, czyli świadek syn (вид = wit, очевидец = witness). Nacht (noc) to ночъ, jednak Abraham i Torok proponują formę przysłówkową ночъю (nосу), po to zapewne, by móc usłyszeć: „not you”34. Stąd: „Świadkiem - syn, nie ty”. Dalsza część tego zdania złożonego brzmi: „und Ich in meinem Bett liege” („i że leżę w łóżku”) ${ }^{35}$. Tym razem jednak

J. Derrida (Fors: The Anglish Words, s. xiii) pisał, że Słowarium „nie jest posłuszne żadnemu prawu [...], zwłaszcza porządkowi filozoficznemu [...], lecz nie przestrzega też zwykłego porządku psychoanalizy".

Wulf i Felcman tłumaczą: „Мне снилось, что - ночь”. 
przeczytane zostało ono w nieco inny, prostszy sposób, bo bez pośrednictwa rosyjskiego. „Bett” to „bed” (łóżko), z tym że zdeszyfrowane zostało „fonicznie” jako spójnik przeciwstawny „but” (lecz). Następne słowo „lie” („I was lying") to angielski homonim oznaczający zarówno leżenie, jak i kłamstwo. I na tej homonimii oparto przekład: „leżę w łóżku” jako „lecz on kłamie” (nieco zaskakujący, bo zaimek „on” został wprowadzony całkiem arbitralnie, a pominięto obecny w niemieckim oryginale zaimek osobowy „Ich” oraz zaimek dzierżawczy „meinem”, „moim”). Po złożeniu dwóch członów otrzymujemy taką oto wypowiedź: „Świadkiem jest syn, nie ty, lecz on kłamie”. Następnie po czterech kolejnych zdaniach, których tu nie prezentujemy, pojawia się wcześniej zdekodowana fraza: „Prawda jest taka, że świadek otworzył się przede mną jako chłopiec".

Najwyższa pora wyjawić nazbyt już długo skrywaną hipotezę scalającą, gdyż - by zrozumieć (s)kryptogram Człowieka-wilka - oprócz słownika potrzebujemy jeszcze czegoś w rodzaju gramatyki i ramy modalnej. To, z czym mamy do czynienia w analizowanym śnie, zakładają francuscy psychoanalitycy, to bardzo nerwowy dialog (stychomytia, bo to scena niczym z tragedii). Zapis marzenia sennego to zaszyfrowana rozmowa, a właściwie kłótnia, której chłopiec był świadkiem, między guwernantką a matką toczona w jakimś dziwnym anglo-rosyjskim pidżinie. Awantura dotyczyła nie czego innego tylko sceny pierwotnej właśnie. Z tym że według Abrahama i Torok to, co zobaczył Sierioża i co nieopatrznie wyjawił guwernantce, która z kolei zaczęła szantażować matkę, było jakąś formą seksualnego uwiedzenia siostry przez ojca lub może raczej ojca przez siostrę. Kluczowe oskarżenie angielskiej opiekunki, odszyfrowane po latach z niemieckiego zapisu snu, brzmiało tak: „- Zrozumiałam wielki grzech” („ich sehe mit großem Schrecken”, „i z wielkim przerażeniem ujrzałem"). Rekonstrukcja tego fragmentu przebiegła następująco: Schreck (szrek) = rpex (griech); sehe = see (homonimia: widzieć, rozumieć) = understand (rozumieć). A dalej: „ein paar weiße Wölfe sitzen” („siedzi kilka białych wilków”) - „ein paar” w paronomastycznym przekładzie: paar = пара = a couple (para, dwoje ludzi) , „,weiße Wölfe sitzen”, czyli: „weiße” = wide (szeroki); „Wölfe sitzen" = wolves sitting = wolf + ing = wolfing [wolf + In] = гульфик (rozporek) ${ }^{36}$. Otrzymujemy w tekście jawnym: „Szeroko rozpięty rozporek”. Następnie: „Es waren sechs oder sieben Stück” („Их было шесть или семь штук”, „sześć czy siedem”). Łańcuch asocjacji

36 Równanie, niezbyt przekonujące, zbudowane zostało, jak się wydaje, na asonansie, wzmocnionym powtarzalnością śródgłosowej zbitki „If” (ulfi). 
tym razem przedstawiał się tak: „sechs [...] Stück” = pack of six = шесть = шестьёрка (szóstka) = сестрёнка ${ }^{37}$ (siostrzyczka) = siestra (siostra), czyli: „Tam była siostra”., - Zrozumiałam wielki grzech. Szeroko rozpięty rozporek. Tam była siostra" - wykrzykuje guwernantka. Matka gwałtownie zaprzecza, twierdząc, że jej syn kłamie...

Chłopiec, zafascynowany i przerażony, był naocznym świadkiem tego traumatycznego zdarzenia, o którym mowa. A następnie został w tym rodzinnym dramacie, niczym w sądzie, powołany przez guwernantkę na świadka, na świadka oskarżenia, a ostatecznie pozostawiony samemu sobie, rozdarty między pragnieniem (siostry, która była jego preferowanym obiektem seksualnym) a milczeniem, wynikającym z konieczności zachowania w tajemnicy rodzinnego wstydliwego sekretu (siostra była równocześnie ideałem Ja). „Będąc na jego miejscu, o mój bracie, co byś zrobił?" - pytają nas w poetyckim zakończeniu swej książki jej autorzy.

Le Verbier de l'Homme aux loups jest próbą odpowiedzi na pytanie, co ów chłopiec-świadek, naonczas Sierioża, później Wolfsmann, zrobił i dlaczego tak postąpił. Interpretacja jego rozlicznych dziecięcych a też późniejszych kłopotów, i psychicznych, i somatycznych, oraz życiowych wyborów i zachowań została oparta na wspomnianej już hipotezie inkorporacji. Inkorporację Abraham i Torok rozumieją dosłownie i „antymetaforycznie” jako w-cielenie, czyli fantazmatyczne pochłonięcie i umieszczenie wewnątrz własnego ciała utraconego lub nieobecnego obiektu, a następnie psychiczną kohabitację i identyfikację z tym tworem, który został już - niczym poczwarka w kokonie ${ }^{38}$ - zamknięty w psychicznej krypcie: sekretnym grobowcu zbudowanym w fałszywej nieświadomości w Ja ${ }^{39}$. Zwróćmy uwagę, że inkorporacja jest

37 Zapis poprawiony.

N. Abraham, M. Torok "The Lost Object-Me", s. 141.

Owa krypta wraz z jej sekretną zawartością może następnie zostać - jako nescience (niewiedza) - przekazana potomstwu na drodze transpokoleniowego dziedziczenia traumy. Dziecko dostaje wtedy niejako w psychicznym spadku wstydliwy sekret rodzica, jednak zupełnie nie jest świadome, że poza wieloma różnymi "dobrami" odziedziczyło również "szkielet w szafie". Nie wie nawet, że owa szafa-krypta została umieszczona w jego psychice. Potomek staje się tym samym bezwolnym wykonawcą testamentu Innego, sceną działania negatywnych sił, bowiem "fantom", który go nawiedza, to pustka, próżnia, nieobecność, luki. „To, co nawiedza, to wcale nie zmarli - pisał Abraham - lecz puste miejsca pozostawione w nas przez tajemnice innych". Obiektywizacja tej nicości, fantom właśnie, wpływa na czyny osobnika, decyduje o jego wyborach i zachowaniu. Zob. N. Abraham Notes on the Phantom: a Complement to Freud's Metapsychology, w: The Shell and the Kernel; N. Abraham The Phantom of Hamlet or The Sixth Act Preceded by The intermission of "truth", w: The Shell and the Kernel; E. Rashkin For a New 
przez autorów Le Verbier traktowana jako zjawisko zdecydowanie negatywne, jako antyintrojekcja. Twórcą terminu introjekcja był Sándor Ferenczi (1909), który ukuł ten termin na określenie postawy charakterystycznej dla neurotyków, lecz pokazywał, że mechanizm ten w mniejszym lub większym stopniu i przede wszystkim bardziej świadomie wykorzystują wszyscy ludzie. W ujęciu Ferencziego introjekcja to antonim projekcji (postawy charakterystycznej dla paranoików), czyli rzutowania swego wnętrza, np. własnych złych cech, na inną osobę. Według autora Thalassy introjekcja to trwający całe życie p r o c e s poszerzania Ja przez wprowadzanie do niego w fantazji elementów świata zewnętrznego ${ }^{40}$. Proces ten zapoczątkowywany jest relacją dziecka z matką, która zaopatruje je w słowa i tym samym pośredniczy w rozumieniu przez nie jego własnej rzeczywistości wewnętrznej, popędowej; sprawia także, że w ostatecznym rozrachunku utrata obsadzonego obiektu nie staje się równoznaczna z utratą siebie (jak w melancholii). Introjekcja jest, powtórzmy, wymagającym czasu i wysiłku procesem, często bolesnym (jak np. żałoba), natomiast fantazja inkorporacji, jak wyjaśniają Torok i Abraham, działa natychmiast ${ }^{41}$, niczym magiczna sztuczka, wykonana w nadziei odczynienia, zanegowania (a nie przepracowania) traumatycznego wydarzenia, zwłaszcza utraty ukochanego obiektu. To działanie, które jedynie „symuluje głęboką przemianę wewnętrzną”, a „czyni to przez literalne potraktowanie czegoś, co ma znaczenie li tylko figuratywne" ${ }^{\text {42 }}$. Jak konkludowała Torok, w inkorporacji „zabroniony obiekt zostaje umieszczony w Ja, po to by zrekompensować

Psychoanalytic Literary Criticism: The Work of Abraham and Torok, w: Family Secrets and the Psychoanalysis of Narrative, Princeton University Press, New York-Oxford 1992; M. Yassa Nicolas Abraham and Maria Torok - the Inner Crypt, "The Scandinavian Psychoanalytic Review" 2002 No. 2; Z. Kolbuszewska Transpokoleniowy fantom, s. 305-307.

S. Ferenczi On the Definition of Introjection (1912), w: Final Contributions to the Problems and Methods of Psychoanalysis, ed. M. Balint, transl. E. Mosbacher et al., Brunner/Mazel, London-New York 2002, s. 316. Ferenczi tak tłumaczył swoją koncepcję: „W zasadzie człowiek potrafi kochać tylko siebie, a jeśli kocha jakiś obiekt, to wprowadza go do Ja. To tak jak z żoną biednego rybaka w bajce. Na jej nosie w wyniku klątwy wyrosła kiełbasa, a ona każde dotknięcie tej kiełbasy odczuwała tak, jakby to była jej własna skóra, i gwałtownie protestowała przeciwko jakimkolwiek próbom odcięcia tej narośli: my również jako nasze własne odczuwamy całe cierpienie zadane kochanemu obiektowi. Posłużyłem się terminem introjekcja na określenie wszystkich takich narośli, każdego takiego wprowadzenia kochanego obiektu do Ja" (tamże).

Różnica między introjekcją a inkorporacją została obrazowo porównana przez autorów The Shell and the Kernel do różnicy między praktycznym opanowaniem leksyki obcego języka a kupnem i posiadaniem słownika.

N. Abraham, M. Torok Mourning or Melancholia, s. 126. 
utraconą przyjemność i nieudaną introjekcję"43. Z jednej strony więc trik inkorporacji pozwala na fantazmatyczną realizację pragnienia, z drugiej - jak w innym tekście pisali psychoanalitycy - służy zakamuflowaniu rany, bowiem „powiedzieć o niej otwarcie oznaczałoby zniszczyć całą topografię"44. Do inkorporacji dochodzi wtedy, gdy utrata nie może być z jakiegoś powodu uznana, zaakceptowana i zwerbalizowana. Powodują ją, jak pisali Abraham i Torok (Mourning or Melancholia, s. 130):

Słowa, które nie mogą być wypowiedziane, sceny, które nie mogą być wspomniane, łzy, które nie mogą zostać wylane - wszystko to będzie połknięte razem z traumą, która doprowadziła do utraty. Połknięte i zachowane. Niewyrażalna żałoba wznosi tajemny grobowiec [tomb] wewnątrz podmiotu. Przedmiotowy korelat utraty - odtworzony ze wspomnień słów, scen, afektów - zostaje pogrzebany żywcem w krypcie [crypt] jako kompletna osoba, ze swoją własną topografią.

Sierioża, w wyniku braku możliwości obsadzenia energią libidinalną wybranych obiektów (siostry, ojca) i jednocześnie w wyniku niemożności wyartykułowania traumy (rodzinnego sekretu i związanego z nim wstydu), inkorporował obraz siostry, potem ojca, a później też obrazy innych postaci (np. samego Freuda) oraz wymyślił pewną strategię negocjowania sensu i przetrwania w takiej niezwykłej konstelacji psychicznej (określonej mianem histerii wewnętrznej). Psychoanalitycy tak ją przedstawili:

Co za sytuacja! Czy jego pożądanie pokrywa się z pożądaniem żywionym przez „Gościa”, czy też jest biegunowo odmiennie - rezultat pozostaje taki sam: całkowita niemożność dosięgnięcia siebie. Wtedy, kiedy chciał być „wykastrowany”, to, czy czynił to powolny życzeniu zazdrosnej siostry, czy też, by naśladować ją [w scenie] z Ojcem? Czy miłości Ojca pożądał dla siebie, czy dla zamieszkującej go siostry? Obraz, w którym się później zakochał, został wyhodowany na jego własnym libido, czy na libido Ojca? W którąkolwiek nie obróciłby się stronę, zawsze stawał twarzą w twarz z tą samą niemożliwością bycia sobą. Znajdował się niejako w pułapce.

M. Torok The Illness of Mourning and the Fantasy of the Exquisite Corpse (1968), w: The Shell and the Kernel s. 113.

N. Abraham, M. Torok "The Lost Object - Me": Notes on Endocryptic Identifiaction (1975), w: The Shell and the Kernel, s. 142. 
Był odgrodzony od innych i - nie będąc w stanie ich przyswoić - mógł ich jedynie w siebie włożyć, tak jak to zrobił z siostrą. Zaludnił swój wewnętrzny świat istotami zarówno łagodnymi, jak i złośliwymi, byli to m.in. Ojciec, Matka, Niania, Nauczyciel niemieckiego, Lekarz i w końcu Psychoanalityk jako Terapeuta. Pierwsza inkorporacja przyciągnęła następne jak magnes opiłki żelaza. Człowiek-wilk utożsamiał się, rozmawiał, spiskował z każdą z tych postaci z osobna. Jego życie to ciągłe manewrowanie w celu uniknięcia niezręcznych spotkań i niedyskrecji. ${ }^{45}$

Czy tak ukazany casus Człowieka-wilka jest jedyny w swoim rodzaju, czy może charakterystyczny dla pewnej klasy przypadków? Czy zaprezentowany tu zakodowany język i reguły jego deszyfracji są jednostkowe, czy też dają się uogólnić? Jeśli to pierwsze, to cała operacja translacji jawi się jako bardzo nieekonomiczna, jako li tylko frapująca i niezwykle ryzykowna rekonstrukcja pewnego szyfru indywidualnego, ale jednocześnie niepozwalająca rozumieć nieczytelne przekazy innych. Freud wykorzystywał strategie wypracowane przy analizie marzeń sennych (kondensacja, przesunięcie, odwrócenie) do interpretacji innych tekstów i obrazów. Również działania Torok i Abrahama były nakierowane przede wszystkim na stworzenie pojęć metapsychologicznych. Według autorów The Shell and the Kernel ukuty przez nich - w trakcie badania zaburzeń procesu introjekcji - termin kryptoforia (nosicielstwo krypty) mógłby zostać efektywnie wykorzystany w diagnozach posługujących się dotąd zazwyczaj pojęciami fetyszyzmu, hipochondrii, psychozy maniakalno-depresyjnej, zaburzeń żałoby ${ }^{46}$.

Jeden z opisanych przez Torok i Abrahama współczesnych przykładów kryptoforii, pochodzący z ich własnej praktyki analitycznej, to przypadek chłopca kleptomana, który kradł m.in. damską bieliznę. W trakcie terapii okazało się jednak, że czynił to w wyniku endokryptowej identyfikacji z nieżyjącą już siostrą. W psychice brata dziewczyna była ciągle żywa i właśnie wchodziła w okres dojrzewania: siostra, jak tłumaczył później chłopak, „w wieku 14 lat potrzebowałaby [przecież] biustonosza"47.

Człowiek-wilk stał się nosicielem krypty, w momencie gdy uświadomił sobie, że jest niebezpieczny dla rodziców. Zaczął też obawiać się samego

\footnotetext{
45 N. Abraham, M. Torok The WolfMan's Magic Word, s. 5.

46 Tamże, s. Ixxii.

47 N. Abraham, M. Torok Mourning or Melancholia, w: The Shell and the Kernel, s. 130-131.
} 
siebie, własnych wewnętrznych impulsów i pragnień. Ze swego traumatycznego snu o wilkach na orzechu obudził się więc po to - jak jego casus opisali Torok i Abraham - by zapaść w kolejny sen, tym razem "quasi-hipnotyczny sen wywołany pragnieniem matki", żeby prawda nigdy nie wyszła na jaw. Chłopiec zaczął więc budować własne życie popędowe na fundamencie "niewypowiadalnych", stłamszonych i semantycznie powykręcanych słów. Słów będących wszakże rekompensatą utraconej przyjemności, słów-rzeczy dających orgiastyczną przyjemność, osiąganą dzięki kamuflażowi i językowej ekwilibrystyce. Abraham i Torok w opozycji do Freuda tak sformułowali własną diagnozę przypadku Człowieka-wilka:

Człowiek-wilk - nie zdradzając nikogo - stworzył [...] tajemne, magiczne słowo, które pozwalało mu osiągać prawdziwą lub wysublimowaną gratyfikację seksualną. Tym słowem było: tieret.

Miał [on] również inne tajemne skarby: gulfik (rozporek), sekretny atrybut ojca, prawdziwe imię jego ideału przekształcone w wilka, jego zaszyfrowane nazwisko. [...] trzecie zamaskowane słowo, [to] widiec. $[\ldots]$

Te trzy słowa: widiec (świadek), gulfik (rozporek) i tieret (trzeć) tworzą trzy niewidzialne, acz solidne filary wzniesione przez Człowieka-wilka na podłożu jego niemożliwego pragnienia, by zająć jakieś miejsce w scenie, którą widział, prawdziwej „scenie pierwotnej”. Na tych trzech kolumnach spoczęło jego zakleszczone życie, które wiódł [...] pod przemożnym wpływem dziecięcej hipnozy. ${ }^{48}$

„Kolumny” naw bocznych - posłużmy się wyobrażeniem budowli sakralnej, wszakże i tu chodzi o pewnego rodzaju architekturę duchową, o świątynię psyche - o nazwach gulfik i widiec zostały wzniesione, jak pokazaliśmy w trakcie wcześniejszej prezentacji analizy sennego koszmaru, przede wszystkim z materiału brzmieniowego, z „rymów”, jako efekt pracy permutacyjnej i przekładowej - interlingwalnej translacji paronomastycznej. „Filar centralny”: tieret, tytułowe „magiczne słowo” Człowieka-wilka, powstał jednak, jak przekonują Abraham i Torok, inaczej: w wyniku przekształceń kryptonimicznych.

Wróćmy na moment do wykładni snu o wilkach. Przypomnijmy, że liczba drapieżników doprowadziła badaczy - przez asocjacje brzmieniowe - do idei siostry: шесть $\rightarrow$ шестьёрка (szóstka) $\rightarrow$ сестрёнка (siostrzyczka) $\rightarrow$ 
siestra (siostra). Siostra i wilk. Inny przykład współwystępowania tej pary znaleźli w koszmarze o gwieździe i półksiężycu: zwiezda - luna to siestra i buka, siostra i wilk. Posługując się językiem poetyki, moglibyśmy rzecz ująć następująco: w polu stylistycznym siostry z jakiegoś powodu (zawsze?) pojawia się wilk. W wyobraźni Człowieka-wilka te akurat słowa przyciągają się i łączą (jak np. róża, lilia, łono i liść w poezji Słowackiego ${ }^{49}$ ). Przy quasi-bachelardowskim założeniu, że snami i symptomami Człowieka-wilka rządzi jakiś ukryty mechanizm, że jego opowieści stanowią swoistą całość, jeden „poemat" - kolejny poddany analizie sen, o „wieżowcu”, zaczyna sprawiać kryptoanalitykom pewne kłopoty. Wyrażenie „Wolkenkratzer” to dosłownie: drapacz chmur. Owszem, w niemieckich „chmurach” skrywa się więc „rosyjski" wilk (Wolken $\rightarrow$ wołk), ale siostry tu ewidentnie brak. Czy rzeczywiście? Na jej miejscu znajduje się czynność „drapania”, „skrobania”. Czy może między nimi istnieć jakiś związek? Jaki? Jak rosyjskie słowo небоскрёб mogłoby aludować do siostry? Abraham i Torok zauważają, że w materiale klinicznym dotyczącym Człowieka-wilka stale powracają słowa takie jak: drapać, zadraśnięcie, zadrapanie, skaleczenie, szrama, rak, które semantycznie (a czasem i fonicznie ${ }^{50}$ ) łączą się ze „skrobaniem” i „drapaniem”. Najwyraźniej ten związek widoczny jest w - opisanym przez Ruth Mack Brunswick ${ }^{51}$ - hipochondrycznym traktowaniu przez Pankiejewa własnego nosa. I w przypadku choroby nosa (określonej przez Torok i Abrahama jako lupus seborrheus), i snu o wieżowcu pojawia się ten sam fundament leksykalny: drapanie, blizna, zranienie... cały zestaw określeń odsyłających do idei rany. „Czyż wszystkie te lokucje nie ukrywają jakiegoś innego słowa?” - zastanawiają się psychoanalitycy - „oznaczającego seksualną przyjemność i czyniącego aluzję do tzw. sceny pierwotnej?". Tym słowem mogłoby być тереть (trzeć), zrekonstruowane na podstawie zapamiętanego przez Człowieka-wilka obrazu: erogennej sceny z dzieciństwa, przedstawiającej dziewczynę na kolanach myjącą podłogę (тереть, натирать пол = myć, froterować, szorować podłogę). Słowa тереть і натирать - zakładają psychoanalitycy - zostają całkowicie

49 Swego czasu ciekawie zinterpretował ten związek Stefan Baley Psychoanaliza jednej pomyłki Słowackiego, „Pamiętnik Literacki” 1924/1925.

50 Np. słowo "rak" to po niemiecku Krebs, które anagramatycznie łączy się z rosyjskim skreb (choć należałoby to zapisać: skriob)

Zob. R. Mack Brunswick A Supplement to Freud's "From the History of an Infantile Neurosis", w: The Wolf-Man and Sigmund Freud, ed. M. Gardiner, Hogarth Press and the Institute of Psycho-analysis, Harmondsworth-Ringwood 1973, s. 292-303. 
wyrugowane z aktywnego słownictwa Człowieka-wilka: zinkorporowane jak przedmioty czy osoby, zaczynają autokomunikacyjnie dostarczać satysfakcji poprzez zastępcze mówienie o froterowaniu, szorowaniu, drapaniu. Teraz i obraz wieżowca z marzenia sennego nabiera sensu: „Wolkenkratzer” to przecież „połączenie wilka z seksualną przyjemnością wynikającą z pocierania"52 - a zrazu nieobecna siostra jawi się, wprawdzie niebezpośrednio, jako agens tej zrekonstruowanej czynności. Podobnie zrozumiany zostaje „język nosa": trapiąca Pankiejewa w latach 1924-1926 obsesja związana z ranami na jego nosie, zainfekowanymi zaskórnikami, wyciskaniem pryszczy, każąca mu peregrynować po gabinetach dermatologicznych Wiednia i doprowadzająca go na skraj depresji i samobójstwa - to performatywny, tak to nazwijmy, aspekt prymarnej opowieści, dramaturgiczna „inscenizacja” słowa rozkoszy na... scenie życia.

Тереть (zarówno w sensie „czyścić”, jak i „dotykać na sposób erotyczny”) to właśnie magiczne słowo, które w wypowiedziach Człowieka-wilka nigdy się nie pojawia, ale za to jego „allosemy” się plenią, zasłaniając słowo centralne, zagadują je, ale i do niego skrycie prowadzą, choć nie po linii prostej (jak w przypadku metonimii czy paronomazji). Opowieści, wspomnienia o polerowaniu, szorowaniu, froterowaniu, skrobaniu, wyprawie nad potok Tierek, wyrywaniu (тереби́ть) skrzydełek osie, ale i symptomy oraz lęki dotyczące drapania i zadrapania, rany po pryszczach, też fascynacja pozycją a tergo, wybór żony pielęgniarki o imieniu Teresa (zdrobniale Tierka, „siostra Tierka”) - wszystko to nic innego, jak tylko rodzaj gry, skrywającej język pragnienia, rodzaj strategii kodującej scenę pierwotną z udziałem ojca i siostry.

Zwięzła, ale i nieco enigmatyczna definicja kryptonimii pojawia się na stronie 118 Le Verbier i powiada, że jest to „zastąpienie pewnego słowa przez synonim jego allosemu". Słowo szyfrujące, ukrywające, maskujące inne słowo to tym razem nie paronim (np. "gwiazda" paronomastycznie sugerująca „siostrę" <zwiezda - siestra>), nie metonimia lub synekdocha (np. „nóż” zamiast „zadźgać” czy „garnitur” zamiast „spodnie”), lecz s y no nim allo s e mu. Wprawdzie termin allosem nie funkcjonuje w terminologii literaturo- i językoznawczej, lecz dzięki jego klarownej łacińskiej etymologii i analogii do terminów takich jak: allofon (wariant fonemu), allograf, allomorf czy allonim można nawet bez psychoanalitycznego kontekstu spróbować uchwycić znaczenie i funkcję tego neologizmu. Od razu pojawi się jednak wątpliwość: czym różni się allosem, czyli wariant znaczeniowy, od synonimu - wyrazu 
bliskoznacznego? Jak się wydaje, w przypadku „trzeć” możemy - na podstawie słownika języka polskiego - zrekonstruować następującą rodzinę „allosemantyczną": „1. naciskając, pr z e s u w a ć czymś po czymś, 2. s z o ro w a ć po czymś, 3. p o c i e r a ć czymś coś". Kolejni kuzyni badanego słowa to: „4. rozdrabn i á coś na cząstki za pomocą tarki [...]; 5. rozcierać”, „6. wy ró w ny wa ć, wygład z a ć powierzchnię”, „7. pił ow a ć, rżnąć coś”. Allosemy słowa "trzeć" zostają więc wyrażone przez następujące leksemy: „przesuwać [np. ręka] ", ,,szorować”, ,pocierać”, ,wygładzać” itd. Czy gdy wybierzemy któryś z tych odcieni semantycznych słowa „trzeć”, np. „szorować”, i ustalimy jego synonimy, to tym samym stworzymy listę potencjalnych kryptonimów? Synonimami „szorować” są: „czyścić”, „myć”, ,zmywać”, ,ścierać”, „skrobać”; w przypadku zaś np. „wygładzać” - „ubić”, ,udeptać”, „uprasować”, też „zasymilować”, „, ujednolicić”. Kry p t o n i m a m i „tarcia” - po przepuszczeniu tego leksemu przez filtr allosemii (szorować, wygładzać) i następnie załamaniu wstępnie już przekształconego znaczenia w pryzmacie synonimii - byłyby więc np. „mycie” i „asymilacja”. Czy tak? Czy wyimaginowana historia o kąpieli, mydle i nad wyraz uporządkowanym i higienicznym trybie życia mogłaby więc skrywać zaszyfrowany kryptonimicznie przekaz o "zranieniu" (czy to cielesnym, czy duchowym - powstałym w każdym razie wyniku jakiegoś „ob-tarcia” czy „u-tarczki”), a rzecz o niemożności wyrwania się z kasty i społecznym niedostosowaniu, pochodząca np. z przełomu wieku XIX i XX - opowieść o indywidualnym dramacie seksualnego odrzucenia (związanym np. z brakiem dotyku, z cielesną oziębłością partnera)? W ujęciu Torok i Abrahama np. za-drapanie, za-draśnięcie (царапина), słowa łączące w sobie znaczenie skrobania, szorowania i zranienia, mogą służyć jako maski, czyli kryptonimy, dla niewymawialnego słowa rozkoszy. Na osi synonimii (drapanie - szorowanie) następuje skrzyżowanie z osią allosemii (szorowanie, czyszczenie, froterowanie itd.) i przekierowanie ku słowu tabu: trzeć.

U Abrahama i Torok sprawa kryptonimii nie jest ani całkiem jasna, ani całkiem prosta. Język Cryptonymie jest poetycki, dialogiczny i dyskursywny jednocześnie. Mowa pozornie zależna i mowa niezależna są tu w ciągłym użyciu: "narratorzy” często dopuszczają do głosu swego bohatera, ich wypowiedzi splatają się, mieszają, krzyżują ${ }^{53}$. Dodatkowo, całość sprawia wrażenie jakby była złożona $\mathrm{z}$ dwóch nie do końca jednorodnych części: pierwszej - „psychodramatycznej” (rekonstruującej przyczyny i skutki inkorporacji),

53 Derrida zwracał uwagę w Fors (s. xxv-xxvi) na jednocześnie powieściowy, mityczny, dramaturgiczny charakter wypowiedzi Abrahama i Torok. 
i drugiej - „translatorycznej” (odkrywającej archeonimy, rymy oraz ich przekłady na angielski i niemiecki). Samej strategii kryptonimii - wysuniętej przecież na czoło w tytule - poświęcono w książce o magicznym słowie stosunkowo niewiele miejsca. W sumie dotyczą jej uwagi rozrzucone na 9 stronach i stąd pewne kłopoty z jej konceptualizacją. Może właśnie dlatego nieco inna jej definicja pojawia się u kontynuatorki myśli Torok i Abrahama, Esther Rashkin, która spróbuje połączyć tak ważny w całości dowodzenia Torok i Abrahama aspekt dźwiękowy (paronimy, homonimy) z semantycznym (synonimy). Według propozycji autorki książki poświęconej psychoanalizie narracji pt. Family Secrets, nie dystansującej się wszakże od ujęcia poprzedników ani nie wykazującej odmienności własnej definicji, kryptonim to już nie „synonim allosemu”, ale „homonim synonimu”... Swoje rozumienie Rashkin demonstruje na następującym przykładzie: dajmy na to, że w materiale analitycznym ukryte zostaje słowo „pillar” (słup). Kryptonimiczne szyfrowanie polega na podwójnej operacji: najpierw „pillar” zostaje przekształcony w synonim "post" (słup), a ten następnie zostaje podmieniony przez homonim - „post” (w znaczeniu: „poczta”).W opowieści kryptonimami skrywającymi "słup" będą więc słowa k o j a r z ą c e si ę z pocztą, jak: listy, przesyłki, paczki, stemple itd. Podkreślmy, ani słowo „pillar”, ani „post” (również w znaczeniu „poczta”) nie pojawiają się w tej historii bezpośrednio ${ }^{54}$. Jedynie przez sprowadzenie wielu różnych leksemów (widokówki, telegramy, znaczki) do wspólnego semantycznego mianownika („post”), a następnie usłyszenie go w postaci homonimu możemy odnaleźć ukryte słowo („słup”). Polskim odpowiednikiem tej akurat kombinacji byłby następujący układ leksykalny: słup $\rightarrow$ tyka (synonim) $\rightarrow$ tyka (homonim) $\rightarrow$ zegary, nakręcanie, cykanie, cyferblaty, stopery itd.

Spróbujmy pójść w przeciwnym kierunku: od tekstu zaszyfrowanego do jawnego - od wypełnionej kryptonimami opowieści ku zawoalowanej tajemnicy. W takiej perspektywie np. historia o dębowym zagajniku, żołędziach, szczecinie, kłach, chrząkaniu, matce i młodych dziczkach - mogłaby zostać potencjalnie odczytana jako opowieść skrywająca „lochy” i związaną z nimi wstydliwą tajemnicę arystokratycznego rodu. Wymienione kryptonimy (żołędzie, las, warchlaki itd.) odsyłają bowiem do wspólnego semantycznego mianownika, jakim jest słowo „locha”, które następnie przekierowuje do swojego homonimu, czyli „lochów” (zamku). Z kolei w „architektonicznym romansie rycerskim" o baszcie, fosie, zwodzonym moście, komnatach, wieżach 
mógłby zostać zaszyfrowany rozporek. W tym przypadku nexus semantyczny, zaproponujmy taką wygodną innowację terminologiczną, to: „zamek”, słowo-homonim, którego znaczenie rozszczepia się na: „budowlę" i „suwak”. Opowieść, posuwając się tylko po architektonicznej „rycerskiej” ścieżce semantycznej, skrywa (ale i sugeruje) istnienie innego szlaku - „odzieżowego”: wieże, komnaty, arrasy itd. przez $\rightarrow$ (nexus) zamek $\rightarrow$ dają zamek (potraktowany homonimicznie) i prowadzą ku jego synonimowi, czyli słowu $\rightarrow$ rozporek.

Podsumowując, sen o wilkach w interpretacji Sigmunda Freuda to opowieść o kompleksie Edypa, o retroaktywnie obudzonych lękach kastracyjnych, skrywających biseksualną naturę pacjenta. W ujęciu Nicolasa Abrahama i Marii Torok zaś „poemat” Człowieka-wilka to przede wszystkim rzecz o dramacie inkorporacji. Odczytanie francuskich psychoanalityków ukazuje pierwszoplanową rolę siostry, kochanej i nienawidzonej jednocześnie, siostry wiodącej sekretne pośmiertne życie w ciele i psychice brata.

Z perspektywy Le Verbier czytanie to translacja. Z tym że tłumacz-interpretator znajduje się w niezbyt komfortowej sytuacji. Jak pisał Abraham, analityk przypomina, tłumacza, który

dostał zlecenie przełożenia na inny język wiersza, o którym wie tylko tyle, że istnieje. Wiersz ten znajduje się w zamkniętych archiwach w sekretnym miejscu. W dodatku, napisany został w języku nieznanym poecie i nieokreślonym dla tłumacza. To, co otrzymuje tłumacz, rozpoczynając swe skomplikowane ustalenia, to obrazy i działania, zarówno dziwne, jak i zwyczajne, a również słowa użyte do ich określenia. Jednakże tłumacz jest pewien, że słowa te nie są częścią wiersza, którego szuka.55

Analiza przypadku Człowieka-wilka to równocześnie traktat o sztuce czytania, o czytaniu zakrzywionym, które ujawniając rdzeń „zatrutego” przez inkorporację życia, dochodzi do sensu poprzez słowa-maski, słowa-przykrywki, czyli kryptonimy.

Czy można tak czytać literaturę? Weźmy opowieść, w której mówi się o wiciu, falistych refleksach, wstędze, pławieniu się, smukłym i giętkim młodzieńcu, który nawija się, gadając, panienkach poruszających się zygzakiem, płaskich domach, cienkiej rzeczywistości, pociągu, torze, szpalerze,

55 Podaję za: N.T. Rand, M. Torok Paradeictic: Translation, Psychoanalysis, and the Work of Art in the Writings of Nicolas Abraham, w: N. Abraham Rhythms. On the Work, Translation, and Psychoanalysis, trans. B. Thigpen, N.T. Rand, Stanford University Press, Stanford 1995, S. 153. 
falowaniu, fałdowaniu, drapowaniu, a „wężowy ruch” dotyczy nie tylko członków sprzedawczyń, lecz całej rzeczywistości, która modelowana jest tu przez pełzanie. Ruch w przestrzeni wyznacza linia prosta plus dreszcz. Materiał obrazowy daje się więc łatwo uporządkować pod szyldem: „wąż”, co w rzeczywistości przedstawionej Ulicy Krokodyli nie powinno zbytnio dziwić. Zdziwić mogłaby dopiero „kryptonimiczna” konkluzja, że w historii tej zaszyfrowany został... szlauf ${ }^{56}$. To oczywiście przykład parodii metody, jednak pod piórem subtelnych interpretatorów wyczulonych na szczegół ten rodzaj superpodejrzliwego ${ }^{57}$ czytania może też dać ciekawe efekty. Na przykład Esther Rashkin świetnie łączy psychoanalityczne intuicje Abrahama i Torok ze strategią close reading ${ }^{58}$, interpretacyjną śmiałość z twardymi tekstowymi argumentami, której efektem są świeże odczytania dramatów i prozy Villiers de Isle Adama, Conrada, Balzaka, Jamesa, Poego, Wilde'a, czy filmów takich jak Uczta Babette i Ostatnie tango w Paryżu. Oprócz Rashkin w „abrahamowym” duchu literaturę (też komiks) interpretowali m.in. Nicholas Rand, Marie-Ange Depierre, Serge Tisseron, Claude Nachin, Fabio Landa, Allan Lloyd Smith, Marek Wilczyński, Colin Davis ${ }^{59}$.

Interpretacja kryptonimiczna rodzi się z braku, z braku znaczenia, z doświadczenia sensu zablokowanego lub z impasu spowodowanego zniekształceniem informacji, nieusuwalną, wydawałoby się, nieczytelnością tekstu;

56 W interpretacji kryptonimicznej nie chodziłoby wcale o "symboliczne" zdeszyfrowanie węża jak fallusa - doszłoby bowiem wówczas do „zamknięcia” znaczenia, do reifikacji symbolu.

57 Celem Abrahama było wynaleźć taki rodzaj czytania, który sprawi, że nawet milczenie przemówi. Zob. N.T. Rand, M. Torok Paradeictic, s. 154.

58 Zob. zwłaszcza E. Rashkin Legacies of Gold: Honoré de Balzac's „Facino Cane”, w: Family Secrets; E Rashkin Religioius Transvestitism and the Stigma of Jewish Identity, w: Unspeakable Secrets and the Psychoanalysis of Culture, Suny Press, Albany 2008. Więcej na ten temat piszę w innym szkicu: I. Piekarski Psychoanalityczne close reading, w: Intryga interpretacji, red. A. Fitas, Wydawnictwo KUL, Lublin 2016 [w druku]. Choć interpretatorka miewa i wpadki. Za taką uznaję próbę wyczytania antysemityzmu w Krótkim filmie o zabijaniu Kieślowskiego, a również niektóre obserwacje analityczne dotyczące Polski tam zawarte. Zob. E. Rashkin Unmourned Dead, Filtered History, and the Screening of Anti-Semitism in Kieślowski's "A short film about killing”, "American Imago" 2009 No. 3.

Zob. np. N. Rand Le cryptage et la vie des œuvres. Étude du secret dans la textes de Flaubert, Stendhal, Benjamin, Baudelaire, Stefan George, Edgar Poe, Francis Ponge, Heidegger et Freud, Aubier, Paris 1988; S. Tisseron Tintin et les secrets de famille, Librairie Séguier, Paris 1990; M.-A. Depierre Paroles fantomatiques et cryptes textuelles, Champ vallon, Ceyzérieu 1993; N. Rand Psychanalyse et littérature: "Les Fleurs bleues", ou comment se guérir en rêve, w: La psychanalyse avec Nicolas Abraham et Maria Torok, ed. J.-C. Rouchy, Librairie générale française, Toulouse 2001 
która przez przetarcie semantycznego szlaku stwarza w ogóle jakąkolwiek możliwość odczytania, czyni czytelnym nieczytelne ${ }^{60}$; to lektura, która ma detektywistyczny sznyt i dąży ${ }^{61}$ do odsłonięcia tajemnic pogrzebanych w „tekstowej krypcie"; która z założenia jest więc lekturową intrygą lub może zostać potraktowana jako interpretacja intrygancka, a nawet arogancka - próbująca czasem całkiem na poważnie odpowiadać na pytania w rodzaju: ile dzieci miała Lady Macbeth?

Kryptonimia nie jest kluczem do wszystkich tekstów literackich, ale może przydać się przy lekturze tych z kręgu literatury gotyckiej, opowieści niesamowitych ${ }^{62}$, wobec których stosowano dotąd zazwyczaj freudowską kategorię powrotu wypartego - unheimliche (zob. np. paradygmatyczną freudowską analizę Piaskuna E.T.A. Hoffmanna ${ }^{63}$ ). Wydaje się, że może też być remedium na schematyczność odczytań freudowskich czy lacanowskich, zwłaszcza przy analizie motywacji literackich postaci.

60 A. Bush [rec.] N. Abraham, M. Torok. The WolfMan's Magic Word:A Cryptonymy, "SubStance" 1988 nr 2.

61 Niosąc ze sobą niebezpieczeństwo zbytniej dociekliwości, hermetycznej pansemiozy.

62 Zob. Z. Kolbuszewska Transpokoleniowy fantom, s. 302.

63 S. Freud Niesamowite, w: Pisma psychologiczne, przeł. R. Reszke, KR, Warszawa 1997. 


\section{Abstract}

\section{Ireneusz Piekarski}

THE JOHN PAUL II CATHOLIC UNIVERSITY OF LUBLIN

Interpretation as Cryptonymy, or: The Curved Reading of Nicolas Abraham and Maria Torok

This article discusses the reading strategy known as 'cryptonymy' and possible ways in which it can be applied in literary studies. Piekarski presents the analysis of the Wolf Man's case by Nicolas Abraham and Maria Torok - two psychoanalysts who pointed out new interpretive perspectives in both psychotherapy and in literary scholarship. The article outlines the advantages and risks associated with the cryptonymic mode of reading literary works.

\section{Keywords}

cryptonymy, suspicious reading, theory of interpretation, Nicolas Abraham, Maria Torok 